ARTICLE

\title{
Contribution of Arctic seabird-colony ammonia to atmospheric particles and cloud-albedo radiative effect
}

\author{
B. Croft ${ }^{1}$, G.R. Wentworth ${ }^{2, \dagger}$, R.V. Martin ${ }^{1,3}$, W.R. Leaitch ${ }^{4}$, J.G. Murphy ${ }^{2}$, B.N. Murphy ${ }^{5, \dagger}$, J.K. Kodros ${ }^{6}$,
} J.P.D. Abbatt $^{2} \&$ J.R. Pierce 1,6

The Arctic region is vulnerable to climate change and able to affect global climate. The summertime Arctic atmosphere is pristine and strongly influenced by natural regional emissions, which have poorly understood climate impacts related to atmospheric particles and clouds. Here we show that ammonia from seabird-colony guano is a key factor contributing to bursts of newly formed particles, which are observed every summer in the near-surface atmosphere at Alert, Nunavut, Canada. Our chemical-transport model simulations indicate that the pan-Arctic seabird-influenced particles can grow by sulfuric acid and organic vapour condensation to diameters sufficiently large to promote pan-Arctic cloud-droplet formation in the clean Arctic summertime. We calculate that the resultant cooling tendencies could be large (about $-0.5 \mathrm{Wm}^{-2}$ pan-Arctic-mean cooling), exceeding $-1 \mathrm{Wm}^{-2}$ near the largest seabird colonies due to the effects of seabird-influenced particles on cloud albedo. These coupled ecological-chemical processes may be susceptible to Arctic warming and industrialization.

\footnotetext{
${ }^{1}$ Department of Physics and Atmospheric Science, Dalhousie University, 6310 Coburg Road, Halifax, Nova Scotia, Canada B3H 4R2. ${ }^{2}$ Department of Chemistry, University of Toronto, 80 St George Street, Toronto, Ontario, Canada M5S 3H6. ${ }^{3}$ Harvard-Smithsonian Center for Astrophysics, 60 Garden Street, Cambridge, Massachusetts 02138, USA. ${ }^{4}$ Climate Research Division, Environment and Climate Change Canada, 4905 Dufferin Street, Toronto, Ontario, Canada M3H 5T4. ${ }^{5}$ Department of Environmental Science and Analytical Chemistry (ACES) and Bolin Centre for Climate Research, Stockholm University, Svante Arrhenius väg 8, SE-11418 Stockholm, Sweden. ${ }^{6}$ Department of Atmospheric Science, Colorado State University, 3915W. Laporte Avenue, Fort Collins, Colorado 80523, USA. †Present address: Computational Exposure Division, U.S. Environmental Protection Agency, Research Triangle Park, 200 Park Drive, North Carolina 27709, USA (B.N.M); Environmental Monitoring and Science Division, Alberta Environment and Parks, 9888 Jasper Ave NW, Edmonton, Alberta, Canada T5J 5C6 (G.R.W). Correspondence and requests for materials should be addressed to B.C. (email: betty.croft@dal.ca) or to G.R.W. (email: greg.wentworth@gov.ab.ca).
} 
$\mathrm{O}$ ver the past 50 years, the Arctic has been warming more rapidly than the global-mean rate for the Earth ${ }^{1}$. Atmospheric particles, clouds and their interactions play key, but complex, roles in offsetting a substantial portion of the Earth's global-mean radiative forcing from greenhouse gases ${ }^{2}$, yet contribute the largest uncertainty to the total radiative forcing estimate ${ }^{1}$. Within the Arctic climate system there are many delicately balanced inter-connections between processes related to the land, ice, ocean and atmosphere ${ }^{2-7}$. The Arctic is a challenging region to $\operatorname{model}^{6}$, although skill and process understanding is progressing $3,5,7$. In this study, we present and investigate a previously unknown coupling between migratory Arctic seabirds and cloud radiative effects (Fig. 1). This climate coupling occurs through changes in atmospheric particle number in response to seabird-colony ammonia $\left(\mathrm{NH}_{3}\right)$.

Together with gas-phase sulfuric acid $\left(\mathrm{H}_{2} \mathrm{SO}_{4}\right)$ and water, $\mathrm{NH}_{3}$ can form new particles in the atmosphere with diameters of $\sim 1-2 \mathrm{~nm}$ (refs $8-10$ ) that can continue to grow to sizes that affect climate ${ }^{11-13}$. This particle formation process is widely accepted as a key contributor to particle number in the Earth's troposphere, with particle formation rates being highly sensitive to $\mathrm{NH}_{3}$ mixing ratios between about 1 and 100 p.p.t.v. (parts per trillion by volume; ref. 8). If newly formed particles grow by condensation of sulfuric acid, organic vapours and/or other compounds to diameters larger than $\sim 50-80 \mathrm{~nm}$, they could influence climate indirectly by acting as the seeds for cloud-droplet formation, modifying the reflectance of solar radiation by clouds ${ }^{11-13}$. More abundant particles form more-numerous and smaller cloud droplets for a fixed cloud liquid-water content, that in turn increase cloud reflection of solar radiation; a cooling effect ${ }^{12}$. The impact of $\mathrm{NH}_{3}$ emissions from Arctic summertime seabird guano on particle formation and cloud radiative effects has not been previously identified or quantified, and despite the known importance of $\mathrm{NH}_{3}$ for particle formation, there are few $\mathrm{NH}_{3}$ measurements in the Arctic ${ }^{14-16}$.

In the summertime Arctic, the precursor vapours for particle formation arise from natural local sources ${ }^{3,17-19}$. Natural $\mathrm{H}_{2} \mathrm{SO}_{4}$ arises from oxidation of dimethyl sulfide (DMS) that is produced by marine biological activity. Wind facilitates the transfer of DMS from the ocean into the atmosphere, where oxidation produces sulfur dioxide $\left(\mathrm{SO}_{2}\right)$. Ultimately, $\mathrm{H}_{2} \mathrm{SO}_{4}$ is produced either through $\mathrm{SO}_{2}$ aqueous oxidation in clouds or in the gas phase by reaction of $\mathrm{SO}_{2}$ with atmospheric oxidants. Only the latter of these oxidation pathways leads directly to particle formation that increases particle number.

Bacterial hydrolysis of seabird guano produces $\mathrm{NH}_{3}$ (ref. 20), previously linked to particle formation in remote regions downwind of penguin colonies ${ }^{21}$. In the Arctic and near-Arctic regions north of $50^{\circ} \mathrm{N}$, recent emission inventories suggest that migratory seabird colonies emit about $40 \mathrm{Gg}$ of $\mathrm{NH}_{3}$ each year ${ }^{18,19}$, primarily between May and September when some tens of millions of breeding pairs are nesting in the region. Several recent global chemical-transport model (CTM) studies have implemented these or similar seabird-colony $\mathrm{NH}_{3}$ emissions ${ }^{7,14,22}$, although none have investigated the impact of these emissions on size-resolved particle number concentrations, clouds and climate as depicted in Fig. 1. The oceans contribute a relatively smaller amount to Arctic summertime $\mathrm{NH}_{3}$ emissions ${ }^{22}$ and have been identified as a net sink of $\mathrm{NH}_{3}$ in the summertime Canadian Arctic Archipelago ${ }^{14}$. Other particle-precursor vapours of natural origin, which we consider later in our discussion, include extremely low-volatility organic compounds (EL-VOCs), amines and iodine ${ }^{23-26}$.

Wentworth et al. ${ }^{14}$ recently measured summertime atmospheric surface-layer $\mathrm{NH}_{3}$ mixing ratios during a 2014 shipboard campaign in the Arctic as part of a multi-year research project (NETCARE, NETwork on Climate and Aerosols: addressing key uncertainties in Remote Canadian Environments; 'Methods' section) and presented evidence that seabird colonies are significant sources of $\mathrm{NH}_{3}$ in the summertime Arctic. Wentworth et al. ${ }^{14}$ also showed that observed summertime $\mathrm{PM}_{1.0}$ (particulate matter with diameters smaller than $1.0 \mu \mathrm{m}$ ) in the high Arctic at Alert, Nunavut, Canada are significantly more neutralized (indicating the availability of gas-phase $\mathrm{NH}_{3}$ ) than during the rest of the year, when previous aircraft measurements have also indicated Arctic aerosol to be highly acidic ${ }^{27}$. However, the influence of seabird-colony $\mathrm{NH}_{3}$ on particle formation, particle number concentrations and cloud-albedo radiative forcing (Fig. 1) has not yet been examined.

In this study, we quantify particle-number changes and the particle-induced cloud-albedo radiative effect in response to Arctic seabird-colony ammonia emissions. We use the GEOS-Chem-TOMAS (GCT) CTM ${ }^{7,28,29}$ with online aerosol physics and chemistry ('Methods' section and Supplementary Methods) to quantify the impact of seabird-colony $\mathrm{NH}_{3}$ emissions on Arctic atmospheric surface-layer reduced nitrogen (gas-phase $\mathrm{NH}_{3}$ and particulate ammonium $\left(\mathrm{NH}_{4}^{+}\right)$), particle formation, growth and subsequent radiative impacts of particleinduced modification of cloud properties. GCT is a state-of-thescience model for this application as it includes the chemical and physical pathways that connect $\mathrm{NH}_{3}$ emissions to climate through particle formation and condensational growth, balanced by losses due to gas and particle scavenging, both in and below clouds. Our results show that ammonia from Arctic seabird-colony guano makes a key contribution to bursts of newly formed particles that are observed in the summertime Arctic. Our simulations indicate that growth of these seabird-influenced particles yield pan-Arctic-mean cooling tendencies that could be large (about $-0.5 \mathrm{~W} \mathrm{~m}^{-2}$ ) due to particle-induced changes in

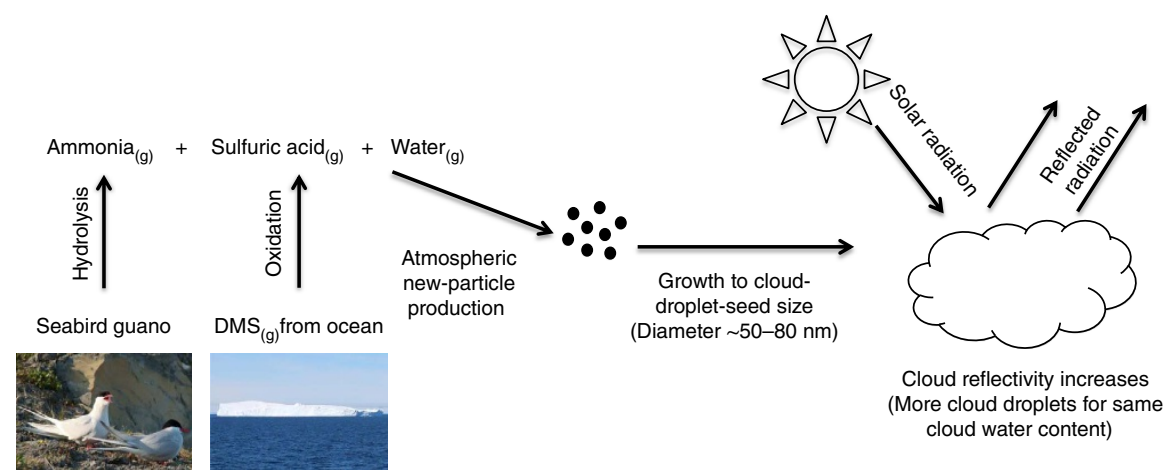

Figure 1 | Seabird-climate coupling. Schematic summary of processes that couple Arctic seabird-colony ammonia emissions with climate. 
cloud albedo. This climate-relevant coupling between Arctic seabirds and cloud radiative effects is explored in the following sections.

\section{Results}

Atmospheric reduced nitrogen from Arctic seabird guano. Figure 2a shows the geographic distribution of total annual Arctic seabird-colony $\mathrm{NH}_{3}$ emissions from recent inventories ${ }^{18,19,30}$ that were implemented in our GEOS-Chem-TOMAS simulations between the months of May and September. Further details about these $\mathrm{NH}_{3}$ emissions are provided in the 'Methods' section. Figure $2 \mathrm{~b}$ shows that in the majority of the ice-free Arctic, the seabird-colony emissions yield a $50-500 \%$ increase in the simulated summertime atmospheric surface-layer total reduced nitrogen (gas-phase $\mathrm{NH}_{3}$ and particulate $\mathrm{NH}_{4}^{+}$) relative to a simulation without the seabird-colony $\mathrm{NH}_{3}$ emissions. For these simulations, $61 \%$ of the Arctic atmospheric surface layer pole-ward of $66^{\circ} \mathrm{N}$ increases in $\mathrm{NH}_{3}$ by more than $50 \%$. This highlights the pan-Arctic potential for seabird-guano $\mathrm{NH}_{3}$ to increase particle formation. The seabird-colony-reduced nitrogen source accounts for about $40 \%$ of the simulated summertime surface-layer total reduced nitrogen and $90 \%$ of the $\mathrm{NH}_{3}$ in the Canadian Arctic Archipelago region north of $70^{\circ} \mathrm{N}$. Wentworth et al. ${ }^{14}$ found that GEOS-Chem-simulated $\mathrm{NH}_{3}$ near Alert was at the lower limit of the range of shipboard measurements, suggesting the Arctic seabird source may be even larger or there may be other unidentified sources. Model-measurement comparisons along the NETCARE ship track in the Canadian Arctic Archipelago region indicates that Arctic seabird-colony emissions can produce $\mathrm{NH}_{3}$ mixing ratios of 10 to 1,000 p.p.t.v., whereas without those emissions, $\mathrm{NH}_{3}$ mixing ratios are underestimated by two to three orders of magnitude in the GEOS-Chem CTM ${ }^{14}$ (Supplementary Figs 1 and 2).

Arctic aerosol neutralization as evidence of ammonia levels. We consider the weekly aerosol neutralization measurements ${ }^{14}$ conducted using filter samples at Alert, Nunavut, Canada as evidence of $\mathrm{NH}_{3}$ levels since there are no ongoing $\mathrm{NH}_{3}$ measurements at Alert. We conduct thermodynamic calculations to estimate the summertime $\mathrm{NH}_{3}$ mixing ratios indicated by the ion concentrations in the Alert aerosol filter measurements ('Methods' section and Supplementary Fig. 3). Our thermodynamic calculations indicate that $\mathrm{NH}_{3}$ mixing ratios above 1 p.p.t.v. (and plausibly as high as 1 p.p.b.v.) are consistent with the summertime measurements at Alert that show the aerosol neutralization ratio typically exceeds 0.7 (Supplementary Fig. 4). These levels of $\mathrm{NH}_{3}$ are consistent with the $\mathrm{NH}_{3}$ mixing ratios measured during the 2014 NETCARE-shipboard campaign ${ }^{14}$. GEOS-Chem simulations indicate that Arctic seabird-colony $\mathrm{NH}_{3}$ emissions provide sufficient $\mathrm{NH}_{3}$ to contribute the majority of these $\mathrm{NH}_{3}$ levels ${ }^{14}$. Outside of summer, the aerosol neutralization ratio based on Alert filter measurements is typically less than 0.4, and our calculations indicate that this corresponds to $\mathrm{NH}_{3}$ levels of less than 1 p.p.t.v. This annual cycle in the particle neutralization state occurs each year and also suggests that seabird-colony emissions are a key source of the $\mathrm{NH}_{3}$ since the timing of the greatest neutralization in the observations coincides with the period of the migratory seabird-colony emissions.

Figure 3 shows that implementation of the seabird-colony $\mathrm{NH}_{3}$ source into the GCT model is sufficient to yield the summertime maximum in aerosol neutralization state at Alert in the GCT simulations. This change increases the simulated monthly median aerosol neutralization ratio from about 0.4 to about 0.9 over June-August in our GCT simulations. Implementation of the seabird-colony emissions into GCT reduces the model-measurement summertime mean fractional bias ${ }^{31}$ in neutralization state from +1.0 to +0.1 . Consideration of methane sulfonic acid (MSA) changes the neutralization ratio at Alert by about 0.05 or less in all months, with the greatest effect in August.

Role of Arctic seabird-colony ammonia in particle formation. Each summer, bursts of particles with diameters larger than $10 \mathrm{~nm}(\mathrm{~N} 10)$ are observed at Alert ${ }^{4}$. Figure 4 shows the time series of the measured N10 particle number concentration from the condensation particle counter at Alert ('Methods' section). Scanning mobility particle sizer (SMPS) measurements (Methods) indicate that these summertime N10 spikes are dominated by particles with diameters smaller than $20 \mathrm{~nm}$, rather than larger accumulation-mode particles that are often a
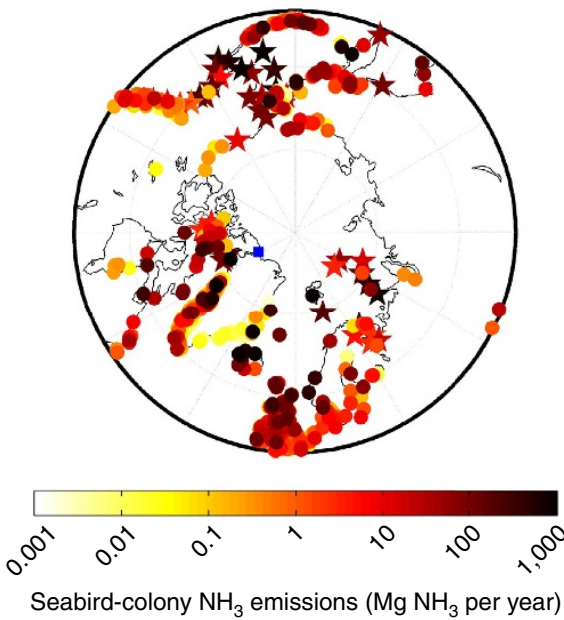

b

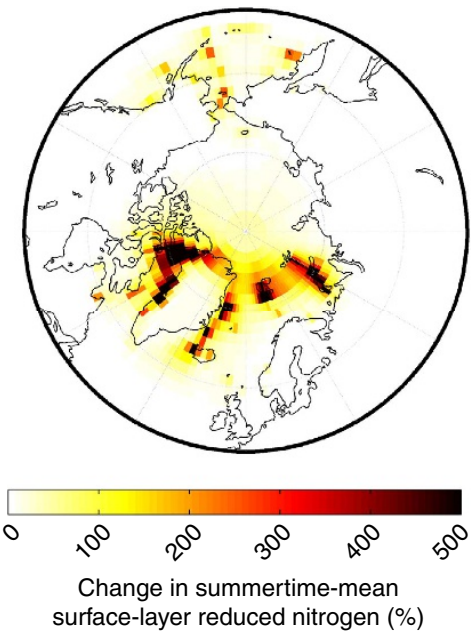

Figure 2 | Arctic seabird-colony $\mathbf{N H}_{3(g)}$ emissions and impacts on atmospheric surface-layer $\mathbf{N H}_{3(\mathrm{~g})}$ and $\mathbf{N H}_{4}{ }^{+}(\mathrm{p})$ mixing ratios. (a) Locations and annual emissions of $\mathrm{NH}_{3(\mathrm{~g})}$ from Arctic seabird colonies. Circles indicate colonies in the Riddick et al. ${ }^{18,19}$ inventory and stars are additional colonies from the Circumpolar Seabird Data Portal ${ }^{30}$. The blue square shows the location of Alert, Nunavut, Canada. (b) Percent change in summertime mean atmospheric surface-layer total reduced nitrogen (gas-phase ammonia $\left(\mathrm{NH}_{3(\mathrm{~g})}\right)$ and particulate ammonium $\left(\mathrm{NH}_{4}{ }^{+}(\mathrm{p})\right)$ attributed to the seabird-colony $\mathrm{NH}_{3}$ emissions for the GEOS-Chem-TOMAS simulations. 


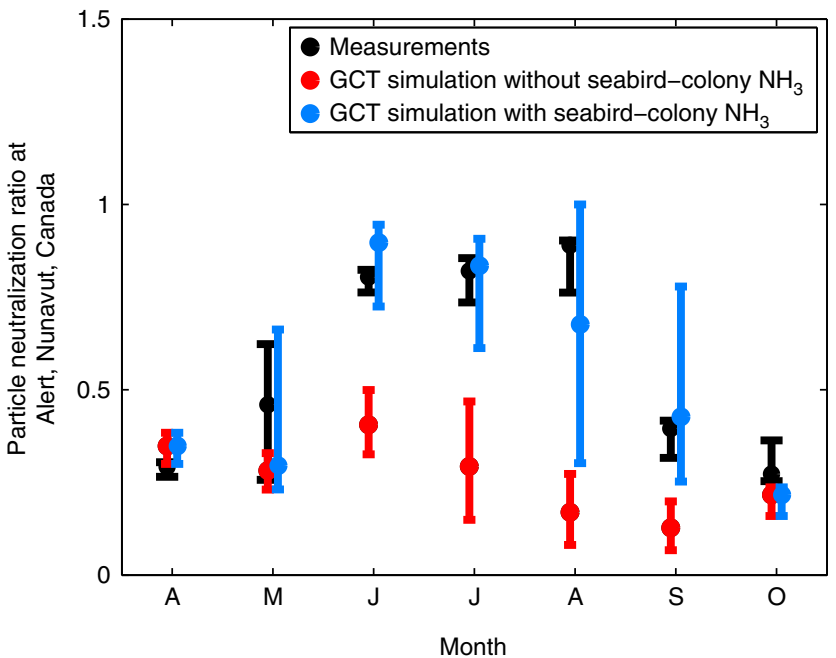

Figure 3 | Aerosol neutralization state at Alert. Monthly median (April to October) aerosol neutralization ratios from filter measurements (black) at Alert, Nunavut, Canada and for the GEOS-Chem-TOMAS (GCT)

simulations with (blue) and without (red) seabird-colony $\mathrm{NH}_{3}$ emissions. Error bars show the 20th and 80th percentiles.

associated with long-range transport. In the summertime, the Arctic atmosphere reaches its most pristine state owing to efficient cleaning by precipitation ${ }^{5-7,32-34}$, which favours particle formation since available vapours are more likely to form new particles because the surface area for condensation on existing particles is reduced by precipitation in low clouds.

Next, we use the GCT model to assess the role of the extra $\mathrm{NH}_{3}$ from Arctic seabird guano in the observed summertime N10 bursts at Alert. Using a state-of-the-science ternary $\left(\mathrm{NH}_{3}+\mathrm{H}_{2} \mathrm{SO}_{4}+\mathrm{H}_{2} \mathrm{O}\right)$ particle formation scheme $e^{35,36}$ ('Methods' section), the GCT model more-closely simulates these N10 bursts when the seabird-colony $\mathrm{NH}_{3}$ source is implemented relative to an otherwise similar simulation without this $\mathrm{NH}_{3}$ source (Fig. 4), reducing the mean-fractional bias ${ }^{31}$ relative to measurements from -0.86 to -0.47 . The timing and magnitude of the N10 bursts is reasonably well represented with the GCT model, but inconsistencies may arise because the seabird-colony emissions are emitted uniformly between May and September and potential sub-grid scale effects related to plume dispersion of seabird-colony $\mathrm{NH}_{3}$ are not considered.

Previous studies have found a variety of trace gases including amines $^{9,37}$, EL-VOCs ${ }^{23-25}$ and iodine ${ }^{26}$ that could also stabilize nascent particles. We considered whether they could contribute to additional particle formation near Alert. During the NETCARE 2014 summertime shipboard campaign near Alert, gas-phase amines were consistently below the instrument detection limit of 0.5 p.p.t.v. ('Methods' section and Supplementary Table 1). These low concentrations of amines might enhance particle formation', but in contrast, gas-phase ammonia observations during NETCARE 2014 ranged from 40 to 870 p.p.t.v., which are levels typically associated with significant particle formation and early growth. If amines did participate in particle formation, this would need to be very close to their source, before the gas-phase amines condense on pre-existing particles or react with gas-phase oxidants. Previous studies indicate lower concentrations of EL-VOCs in the Arctic than needed to fully support the observed particle formation ${ }^{24,38}$. We conducted calculations of the expected contribution from EL-VOC-related particle formation in this region based on current knowledge of EL-VOC sources ('Methods' section) and found a low contribution. Iodine oxides

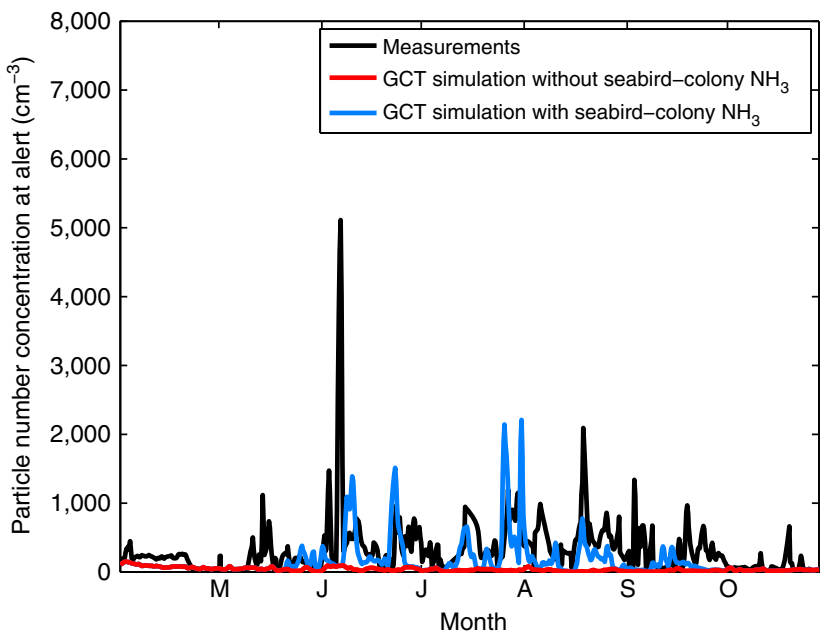

Figure 4 | Summertime bursts of newly formed particles at Alert. Time series of surface-layer number concentration of atmospheric particles larger than $10 \mathrm{~nm}$ (N10) from condensation particle counter (CPC) measurements at Alert from April to October 2011 (black) and as simulated with GCT model, with (blue) and without (red) seabird emissions implemented.

have also been linked to particle formation in Arctic coastal regions ${ }^{26}$. The spatial extent of this influence is not well established. We have no observational constraints on the gas-phase iodine oxides near Alert, so we cannot rule out their additional contributions ('Methods' section). Primary marine aerosols can also contribute to the number of ultrafine particles in certain regions of the Arctic ${ }^{39-42}$, which could regionally reduce the relative contribution of seabird-colony emissions to ultrafine particle number concentrations. On the other hand, MSA can contribute to particle formation if a base exists for the nascent clusters ${ }^{43,44}$, and as a result could increase the relative contribution of seabird-colony emissions to the number of ultrafine particles. However, recent evidence by Giamarelou et al. ${ }^{15}$ suggests that ammonium sulfate is the dominant constituent in sub- $12 \mathrm{~nm}$ particles near the high-Arctic site Ny-Ålesund, Svalbard. This supports our use of the particle-formation scheme based on ammonia, sulfuric acid and water. Given that current knowledge about particle-formation processes is limited, possibly $\mathrm{NH}_{3}$ may act along with other co-emitted trace gases and in concert with MSA in yielding the observed N10-particle bursts at Alert. We consider all of the above together as compelling evidence for the key role of seabird-colony emissions in Arctic particle formation and early growth.

Seabird-influenced particle growth to cloud-relevant size. To influence clouds and radiation, the nascent particles must grow to sizes larger than $\sim 50-80 \mathrm{~nm}$; sizes that act as the seeds for cloud-droplet formation in summertime Arctic clouds $4,12,13$. Our GCT simulations indicate sufficient growth of the seabirdcolony-influenced particles that the number of particles larger than $80 \mathrm{~nm}(\mathrm{~N} 80)$ increases throughout the summertime Arctic surface layer by $10-50 \%$ over most of the Arctic Ocean, with the largest changes near the major seabird colonies, particularly in the Canadian Arctic Archipelago region, and also along the eastern coast of Greenland, towards Iceland (Supplementary Fig. 5). The simulated pan-Arctic-mean surface-layer N80 for August increased from 40.4 to $49.5 \mathrm{~cm}^{-3}$ with the implementation of seabird-colony $\mathrm{NH}_{3}$. Thus, there is sufficient growth of the newly formed particles associated with the extra $\mathrm{NH}_{3}$ from seabird colonies to yield pan-Arctic changes in the number of particles 
that are large enough to potentially act as the seeds for the formation of cloud droplets.

As well, with the seabird-colony ammonia implemented, the simulated regional-mean surface-layer number of cloudcondensation nuclei $(\mathrm{CCN})$ at $0.2 \%$ supersaturation (CCN0.2) over the pack ice of the inner Arctic Basin for August is about $18 \mathrm{~cm}^{-3}$, which is within the range of measurements from the region $^{3}\left(15-30 \mathrm{~cm}^{-3}\right.$; 'Methods' section and Supplementary Fig. 6). Without this ammonia source and for the same region, the simulated regional-mean surface-layer CCN0.2 for August is $12 \mathrm{~cm}^{-3}$ and the CCN0.2 is less than $10 \mathrm{~cm}^{-3}$ over much of the pack ice region of the inner Arctic, which underestimates the measurements ${ }^{3}$. Over the inner Arctic (north of $80^{\circ} \mathrm{N}$ ), the simulated summertime regional-mean CCN0.2 concentrations are most sensitive to the extra ammonia source at altitudes below about $1.2 \mathrm{~km}$ (changes of about 20-30\%; Supplementary Fig. 7). This suggests that the greatest impacts of the seabird-colony ammonia are on clouds in the lower troposphere. The simulated CCN0.2 concentrations decrease from $500 \mathrm{~m}$ to the surface layer (Supplementary Fig. 7), as do measurement vertical profiles from this region ${ }^{45}$. This decrease towards the surface is thought to be due to efficient particle removal in and below low-level clouds combined with limited mixing into the stable surface layer of air that originates near particle sources (open water, land), rises and is transported into the inner Arctic above the surface layers ${ }^{3}$.

Condensation of sulfuric-acid and low-volatility organic vapours contributes to particle growth in our simulations. Sulfate and organic carbon account for about 70 and $30 \%$, respectively, of the simulated mass of particles with diameters of about $80 \mathrm{~nm}$. There is considerable uncertainty about primary organic aerosol and low-volatility organic-vapour precursor emissions from the oceans ${ }^{17}$. Thus, our simulations, while exhibiting skill in representing Arctic particle number and size distributions ${ }^{7}$, may miss additional particles and vapours that could enhance particle number and growth.

Seabird-influenced cloud-droplet number concentration change. Figure 5a shows that implementation of seabird-colony emissions in the GCT model increases simulated pan-Arctic cloud-droplet number concentrations (CDNCs) by over $10 \%$ through most (64\%) of the Arctic boundary layer under the assumption of fixed cloud liquid-water content. Maximum changes exceed 50\% in close proximity to the larger seabird colonies. The simulated aerosol activation treatment is described in the 'Methods' section, including details about the supersaturation and particle size that activates (Supplementary Figs 8 and 9). The simulated CDNC is broadly consistent with the measurements of Leaitch et al. ${ }^{46}$ made during the summertime 2014 NETCARE campaign in the Canadian Arctic Archipelago region (Supplementary Fig. 10). Leaitch et al. ${ }^{46}$ found a median CDNC of 10 and $100 \mathrm{~cm}^{-3}$ for clouds below and above $200 \mathrm{~m}$, respectively. Our simulated CDNC falls within that general range, albeit with a weaker, but similar, vertical gradient. The agreement with these recent measurements ${ }^{46}$ gives confidence in the simulation of CDNC. Next we investigate the cloud-albedo radiative effect under the assumption of fixed cloud liquid-water content.

More-numerous and smaller cloud droplets (for the same cloud liquid-water content) make clouds more reflective of solar radiation, which has a cooling effect ${ }^{1-13}$. Here we restrict our investigation to this single aerosol-cloud radiative effect. Further study is needed to consider additional particle-induced cloudalbedo radiative effects related to changes in cloud lifetime, liquid-water content and fractional coverage, which might be particularly relevant in summertime in the pristine region north of about $80-85^{\circ} \mathrm{N}$ (ref. 47). In addition, longwave radiative effects associated with cloud-property changes in response to particle number might be relevant in the low-CDNC limit, particularly in the near-surface layers over the inner Arctic north of about $80-85^{\circ} \mathrm{N}$ where the clouds are not optically thick with respect to longwave radiation ${ }^{47}$. Observations show that Arctic low-cloud layers further above the surface layer $(\sim 200-500 \mathrm{~m}$ and above) tend to have greater cloud droplet number concentrations $^{46}$ for which longwave radiative effects are relatively insensitive to changes in particle number ${ }^{47}$. However, future study is needed to examine the longwave effects of seabirdcolony ammonia, particularly in the inner Arctic and as well to develop understanding of processes controlling aerosol activation to form cloud droplets in this region.

Cloud-albedo radiative effect attributed to seabird ammonia. We conduct an offline calculation of the cloud-albedo radiative effect in response to changes in particle number under constant cloud water content ${ }^{12,48,49}$ ('Methods' section). The mean aerosol indirect effect (AIE) over the Arctic Ocean between our a

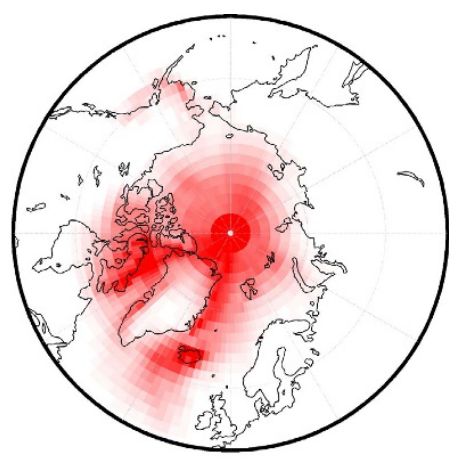

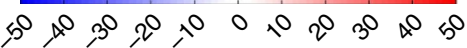

CDNC change with seabird-colony $\mathrm{NH}_{3}(\%)$ b
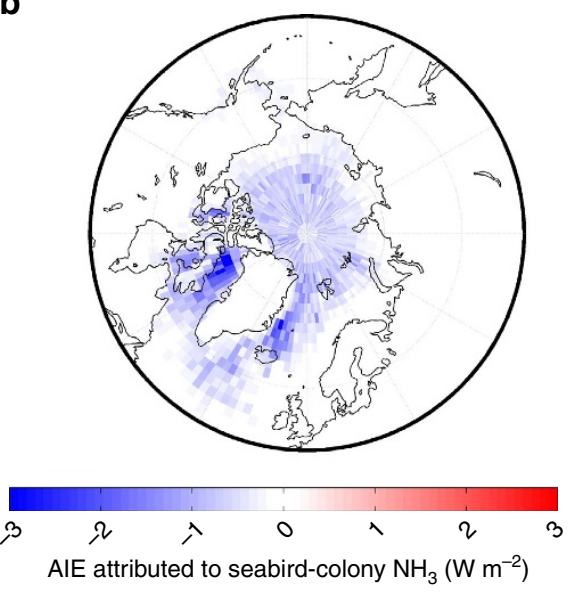

Figure 5 | Pan-Arctic geographic distribution of climate components of the seabird-climate coupling. (a) Percent difference in pan-Arctic summertime mean cloud-droplet number concentration (CDNC) in the atmospheric boundary layer due to inclusion of seabird $\mathrm{NH}_{3}$ emissions in the GEOSChem-TOMAS (GCT) model under the assumption of fixed cloud liquid-water content. (b) Pan-Arctic summertime-mean aerosol indirect (cloud-albedo) radiative effect (AIE) attributed to the seabird-colony emissions. 
simulations with and without the extra seabird-colony $\mathrm{NH}_{3}$ is $-0.5 \mathrm{~W} \mathrm{~m}^{-2}$, and exceeds $-1 \mathrm{Wm}^{-2}$ near the largest bird colonies (Fig. 5b). We find no appreciable change in the direct scattering and absorption related to these additional particles because the particle mass concentrations do not change greatly between simulations, and the size distribution shifts only slightly at the sizes with most-efficient scattering (Supplementary Methods). In the context of current global radiative forcing from $\mathrm{CO}_{2}$ $\left(+1.6 \mathrm{~W} \mathrm{~m}^{-2}\right.$; ref. 50$)$, the negative contribution from the Arctic seabird-influenced cloud-albedo radiative effect is a significant regional effect.

Future work is needed to fill knowledge gaps related to seabird-colony $\mathrm{NH}_{3}$ emissions, the role of MSA, primary organic particles from the oceans and secondary organic aerosols from both marine and terrestrial sources in shaping Arctic particulate mass and number distributions and also cloud processes (cloud formation, growth and lifetime), particularly in the inner Arctic. We conducted sensitivity studies, which show the cloud-albedo radiative effect could be both strengthened and weakened by these processes ('Methods' section and Supplementary Table 2).

\section{Discussion}

Our findings suggest that the pristine summertime Arctic is an environment where changes in particle formation can have a noteworthy impact on cloud radiative effects. Here, we have investigated the contribution of seabird-colony ammonia emissions to Arctic particle-number concentrations and identified a resultant substantial cloud-albedo radiative effect in response to changes in cloud-droplet number for fixed cloud liquid-water content.

The evidence that migratory seabirds are a major source of $\mathrm{NH}_{3}$ in the Arctic and a key contributor to Arctic particle formation draws attention to the connections between the fauna, nitrogen cycle, atmospheric aerosol and aerosol-cloud interactions in the Arctic. Our study highlights the need for multi-disciplinary research, ongoing measurements of $\mathrm{NH}_{3}$, particles and clouds in the Arctic region, and detailed study of the natural Arctic fauna to better understand the details of the related processes. Given the accelerated rate of Arctic warming ${ }^{1,2,51}$, seabird numbers and migratory patterns may change, altering the seabird-guano $\mathrm{NH}_{3}$ emissions in the Arctic. Climate warming may also change other particle sources in the Arctic through oceanic emissions ${ }^{52,53}$, ship traffic ${ }^{54}$ and other anthropogenic pollution. Thus, the relative importance of $\mathrm{NH}_{3}$ from seabird guano to the Arctic climate may be susceptible to future change.

\section{Methods}

Shipboard trace-gas measurements. Measurements of gas-phase $\mathrm{NH}_{3}$ were taken in the Canadian Arctic Archipelago region aboard the Canadian Coast Guard Ship (CCGS) Amundsen during a NETCARE (NETwork on Climate and Aerosols: addressing key uncertainties in the Remote Canadian Environments) campaign from 13 July 2014 to 7 August 2014 (ref. 14). The measurements were conducted in Baffin Bay, Lancaster Sound and Nares Strait. $\mathrm{NH}_{3}$ was quantified using the Ambient Ion Monitor-Ion Chromatograph (AIM-IC) system (Model 9000D, URG Corp.). The AIM-IC is a semi-continuous, on-line instrument that provides hourly measurements of both water-soluble gases and ions in particulate matter with a diameter smaller than $2.5 \mu \mathrm{m}\left(\mathrm{PM}_{2.5}\right)$. Ambient air is pulled through a parallel plate wet denuder, which scavenges water-soluble gases, whereas $\mathrm{PM}_{2.5}$ are collected downstream in a supersaturation chamber. These aqueous samples are then quantified in an online manner using both an anion and cation Ion Chromatograph (ICS-2000, Dionex Corp.). IC calibration was performed offline with aqueous standards, and a system background was determined by overflowing the inlet with zero air (AI 0.0 UZ-T, PraxAir). $\mathrm{An} \mathrm{NH}_{3}$ detection limit of 38 p.p.t.v. was calculated by taking $3 \sigma$ of the background signal. To prevent influence from activities aboard the ship, $\mathrm{NH}_{3}$ measurements are only reported if the following conditions were met: ship speed $>4$ knots, apparent hourly wind direction $\pm 90^{\circ}$ of the bow (where the inlet box containing the denuder and supersaturation chamber was located), and standard deviation of apparent wind direction $<36^{\circ}$
Detection limits for six different amines during this study are given in Supplementary Table 1 and were determined in a similar manner to $\mathrm{NH}_{3}$. The instrumental backgrounds for amines are very low and there was no signal from any amine listed in Supplementary Table 1 during the zero air experiments conducted throughout the NETCARE 2014 shipboard campaign. As a result, we calculate the detection limits by taking three times the minimum peak area that can be integrated and convert this to either a mixing ratio (gas-phase) or mass loading $\left(\mathrm{PM}_{2.5}\right)$. Not once throughout the entire study did any amine exceed the detection limit. Thus, we did not find clear indications in the study region near Alert that the amines typically associated with particle formation (particularly dimethylamine) were available at levels typically associated with significant particle formation ${ }^{9}$, although particle formation could have occurred very near to source before loss to particle phase or further gas-phase oxidation reactions.

Iodide $\left(\mathrm{I}^{-}\right)$in $\mathrm{PM}_{2.5}$ and gas-phase hydrogen iodide (HI) can also be detected by the AIM-IC. Detection limits of $18 \mathrm{ng} \mathrm{m}^{-3}$ and 0.7 p.p.t.v. were calculated for $\mathrm{I}^{-}$and HI, respectively. Similar to the amines, neither $\mathrm{I}^{-}$nor HI was observed above the detection limit during the NETCARE 2014 shipboard campaign. Unfortunately, we have no measurements of iodine oxides in the Alert region, such that we cannot rule out their potential additional contributions to particle formation, particularly as iodine has been linked to particle formation in certain coastal regions ${ }^{26}$

Thus, while the potential exists for amines and iodine to make additional contributions to particle formation in our study region, we were unable to ascertain their influence from available measurements, whereas we have clear evidence of $\mathrm{NH}_{3}$ at levels known to strongly influence particle formation and early growth. We recommend future study of the composition of nascent aerosol clusters in the Arctic to address these uncertainties.

Alert particle measurements and thermodynamic calculations. Particle size distribution measurements at Alert have been ongoing since March 2011 (ref. 4). The total number concentration of particles with diameters larger than $10 \mathrm{~nm}$ at Alert is measured with a TSI 3772 Condensation Particle Counter (CPC). The 3772 CPC was initially compared with a TSI 3775 CPC, which counted particles larger than $4 \mathrm{~nm}$ and was operating temporarily at the site, and the differences were found to be $<10 \%$ when particle sizes were large enough such that both counters counted all the particles. The particle size distributions from 20 to $500 \mathrm{~nm}$ diameter are measured with a TSI 3034 Scanning Mobility Particle System (SMPS), verified for sizing on site using mono-disperse particles of polystyrene latex and of ammonium sulfate generated with a Brechtel Manufacturing Incorporated Scanning Electrical Mobility Spectrometer, and for number concentrations through comparison with the TSI 3772 Condensation Particle Counter (CPC). The 3772 CPC also compares to within $10 \%$ with SMPS when particle sizes are large enough for all the particles to be counted by both the instruments.

In addition, weekly samples of the ambient aerosol are collected on Teflon filters located inside the Global Atmosphere Watch (GAW) Observatory at Alert. The sampling uses a cyclone to restrict te particles to smaller than $1 \mu \mathrm{m}$. Ion chromatography is conducted for the analysis of major inorganic ions (including $\mathrm{SO}_{4}^{2-}$ $\mathrm{NH}_{4}^{+}$and $\mathrm{NO}_{3}^{-}$) and MSA. Further details about the sample handling, analytical methods and quality control are discussed by Leaitch et al. ${ }^{4}$ and $\mathrm{Li}$ and Barrie ${ }^{55}$.

There are no ongoing measurements of $\mathrm{NH}_{3}$ at Alert. In addition, since the particle composition measurements at Alert are based on integrated weekly filters, it is not possible to infer by calculations the maximum, minimum or average amount of $\mathrm{NH}_{3}$ with high temporal resolution. However, we conducted thermodynamic calculations with the E-AIM (Extended Aerosol Inorganics Model) model ${ }^{56,57}$ to provide an estimate of the order of magnitude of $\mathrm{NH}_{3}$ mixing ratios present near Alert during July and August (Supplementary Fig. 4). In July-August at Alert, measurements indicate that average daily temperatures are typically $0-10{ }^{\circ} \mathrm{C}$, and relative humidity is typically between 74 and $82 \%$. We use these ranges of temperature and relative humidity as inputs to the E-AIM model.

Meng and Seinfeld ${ }^{58}$ indicate that the timescale for equilibration depends strongly on the particle diameter, and the uptake coefficient for the gas-phase substance. Recent summertime ground, aircraft and ship-based measurements in the Canadian Arctic Archipelago indicate that the particles are predominantly smaller than $100 \mathrm{~nm}$ in diameter (favouring fast equilibration), but also significantly neutralized (slowing equilibration timescales by decreasing the uptake coefficient). Recent ship-based observations in the Canadian Arctic Archipelago by Wentworth et al. ${ }^{14}$, found significantly more ammonia in the gas phase than the particle phase over most of the region. Bird colonies represent concentrated sources of $\mathrm{NH}_{3}$ to the model atmosphere, which likely equilibrates the particles with this new burden of ammonia quickly in the downwind direction. In our simulations, this may lead to slight underestimates of the true mixing ratios of gas-phase ammonia, and slight overestimates of particle-phase ammonium within the first few hours of transport from the source. Even though more neutralized particles take longer to equilibrate, a large increase in gas-phase ammonia will only have a moderate impact on their chemical composition (since they are nearly neutralized), so model predictions assuming equilibrium will not result in large errors.

Given that any biases related to assumptions of equilibrium partitioning would cause a low bias in gas-phase ammonia throughout the region, this suggests that our model estimate provides a lower bound on the potential impact of seabird colonies on particle formation. 
Seabird ammonia emissions. Seabirds have a nitrogen-rich diet consisting primarily of marine biota. A significant portion of this nitrogen is excreted in the form of uric acid $\left(\mathrm{C}_{5} \mathrm{H}_{4} \mathrm{O}_{3} \mathrm{~N}_{4}\right)$, which undergoes bacterial degradation in the presence of water $\left(\mathrm{H}_{2} \mathrm{O}\right)$ and oxygen $\left(\mathrm{O}_{2}\right)$ to release carbon dioxide $\left(\mathrm{CO}_{2}\right)$ and $\mathrm{NH}_{3}$, according to the reaction shown in equation 1 (ref. 20).

$$
\mathrm{C}_{5} \mathrm{H}_{4} \mathrm{O}_{3} \mathrm{~N}_{4}+1.5 \mathrm{O}_{2}+4 \mathrm{H}_{2} \mathrm{O} \rightarrow 5 \mathrm{CO}_{2}+4 \mathrm{NH}_{3}
$$

The emission inventory for seabird-derived $\mathrm{NH}_{3}$ used in this work was adapted from a global inventory that Riddick et al. ${ }^{18,19}$ developed of $\mathrm{NH}_{3}$ emissions from decomposing seabird guano for over 30,000 different seabird colonies. The foundation of the inventory is a bioenergetics model developed by Wilson et al. ${ }^{59,60}$ that calculates species-dependent $\mathrm{NH}_{3}$ emissions per bird. Riddick et al. ${ }^{18,19}$ used seabird-colony population data from a wide variety of sources to scale up $\mathrm{NH}_{3}$ emissions to the colony level with a global resolution of $0.1^{\circ} \times 0.1^{\circ}$. The inventory is publically available for download ${ }^{19}$. The original inventory provided three different scenarios each containing a different temperature-dependency for $\mathrm{NH}_{3}$ volatilization from seabird guano. Here we adopt scenario 3 (moderate

dependency), which was identified as being the most accurate by Riddick et al. ${ }^{18}$

Riddick et al. ${ }^{18}$ discuss the large uncertainties and lack of standard reporting methods for seabird-colony populations. Population uncertainties are magnified for remote regions (that is, the Arctic) where data on seabird populations are sparse. Hence, the Circumpolar Seabird Data Portal (CSDP) ${ }^{30}$ was used to check for any substantial seabird colonies in the region north of $50^{\circ} \mathrm{N}$ that were not included in the Riddick et al. inventory ${ }^{18,19}$. The $\mathrm{CSDP}^{30}$ is an interactive map that displays total seabird population by species in hexagonal cells (roughly $100 \mathrm{~km}$ across). The total population in each cell was recorded and transformed into an $\mathrm{NH}_{3}$ emission estimate using the bioenergetics mode ${ }^{59,60}$. The emission estimates for each cell in the CSDP were cross-referenced against the Riddick et al. ${ }^{18,19}$ inventory with the same methodology as used by Wentworth et al. ${ }^{14}$. For colonies in the region north of $50^{\circ} \mathrm{N}$ that were present in both inventories, the $\mathrm{NH}_{3}$ emission estimates typically agreed within a factor of 2 (data not shown). Using this methodology, we identified 42 colonies in the region north of $50^{\circ} \mathrm{N}$ either absent or with significantly lower estimates in Riddick et al. ${ }^{18,19}$. The locations and magnitude of annual $\mathrm{NH}_{3}$ emissions of these extra colonies are listed in the Supplementary Tables $3-5$. These additional colonies contributed about $7.6 \mathrm{Gg}$ $\mathrm{NH}_{3}$ to the total annual emissions of about $35.6 \mathrm{Gg} \mathrm{NH} \mathrm{N}_{3}$ in the region north of $50^{\circ}$ N. Although the CSDP is a 'work in progress' and may contain errors, it is currently the best available resource for examining Arctic seabird-colony population at the regional scale. Future studies should focus on constraining the uncertainties in Arctic seabird distribution.

GEOS-Chem-TOMAS model description. The GEOS-Chem-TOMAS chemicaltransport model ${ }^{7,28,29}$ (www.geos-chem.org) includes a detailed oxidant-aerosol tropospheric chemistry mechanism and is used in the interpretation of the atmospheric measurements. Here we describe the model and additional details are in Supplementary Methods. We use GEOS-Chem version 9-02 at $2^{\circ} \times 2.5^{\circ}$ resolution globally, and with 47 vertical layers between the surface and $0.01 \mathrm{hPa}$. The assimilated meteorology is taken from the NASA Global Modelling and Assimilation Office Goddard Earth Observing System (GEOS-5). Our simulations use 2011 meteorology and allow a 2-month spin-up.

In this study, we implemented into GEOS-Chem-TOMAS a total of $35.6 \mathrm{Gg}$ per year of seabird-colony $\mathrm{NH}_{3}$ emissions, all in the region north of $50^{\circ} \mathrm{N}(28 \mathrm{Gg}$ per year following the Riddick et al. inventory ${ }^{18,19}$ combined with additional seabird-colony emissions of $7.6 \mathrm{Gg}$ per year derived using seabird population estimates from the Circumpolar Seabird Data Portal ${ }^{30}$ and the bioenergetics model of Wilson et al ${ }^{59}$ ). The total seabird-colony $\mathrm{NH}_{3}$ emissions for the region north of $50^{\circ} \mathrm{N}(35.6 \mathrm{Gg}$ year) used in our simulations are within the range of the emissions scenarios for this region (18 to $37 \mathrm{Gg}$ per year) that was identified by Riddick et al. ${ }^{18,19}$. To reflect the migratory pattern of circumpolar seabirds, we distributed the annually averaged emissions evenly between 15 May and 15 September ${ }^{61-63}$ The peaks in $\mathrm{NH}_{3}$ emissions from seabird colonies may follow episodes of rain ${ }^{20}$, but we have insufficient information to parameterize that process at this time. Implementation of this updated seabird-colony emissions inventory into GEOS-Chem in two previous studies found greater model-measurement consistency for 2014 surface-layer $\mathrm{NH}_{3}$ (ref. 14) and reasonable agreement with summertime-mean aerosol size distributions at Alert, Nunavut, Canada ${ }^{7}$.

In addition to the seabird-colony emissions, our simulations include other natural and anthropogenic $\mathrm{NH}_{3}$ emissions ${ }^{64}$. Paulot et al. ${ }^{22,65}$ recently evaluated the GEOS-Chem reduced nitrogen simulation and found that the GEOS-Chem model is more likely to overestimate than underestimate the traditional reduced nitrogen sources from the central United States and the Arctic Ocean.

Biomass-burning emissions are from the Global Fire Emissions Database v3 (ref. 66). The model also includes natural and anthropogenic sources of sulfur dioxide ${ }^{27}$ and oceanic DMS concentrations from Lana et al. ${ }^{67}$. Oxidation of $\mathrm{SO}_{2}$ occurs in clouds by reaction with $\mathrm{H}_{2} \mathrm{O}_{2}$ and $\mathrm{O}_{3}$ and in the gas phase with OH. DMS oxidation occurs by reaction with $\mathrm{OH}$ and $\mathrm{NO}_{3}$.

The TOMAS microphysics scheme is coupled to the GEOS-Chem model and tracks the number and mass of particles within each of 15 dry-size sections ${ }^{29}$. The first 13 size sections are logarithmically spaced, and include aerosol dry diameters from approximately $3 \mathrm{~nm}$ to $1 \mu \mathrm{m}$, and two additional size sections represent aerosol dry diameters from 1 to $10 \mu \mathrm{m}$. Growth and loss of particles with diameters smaller than $3 \mathrm{~nm}$ are approximated in the model. The model includes particle growth by condensation of sulfuric acid, organic vapours and MSA. Our simulations include a biogenic secondary organic aerosol source ( $\sim 19 \mathrm{Tg}$ per year) and also enhanced secondary organic aerosol (100 Tg per year), spatially correlated with anthropogenic $\mathrm{CO}$ emissions that is considered non-volatile following D'Andrea et al. ${ }^{68}$ D'Andrea et al. ${ }^{68}$ also explored uncertainties related to the Kelvin effect on retardation of early growth of the particles and found a minor impact on CCN globally. Simulated size-resolved aerosol constituents are sulfate-nitrate-ammonium, sea-spray, hydrophilic organics, hydrophobic organics, internally mixed black carbon, externally mixed black carbon, dust and water. The sulfate-nitrate-ammonium chemistry uses the ISORROPIA II thermodynamic mode ${ }^{69}$. Aerosol hygroscopic growth is a function of grid box mean relative humidity capped at $99 \%$.

The model includes removal of gases and aerosols from the atmosphere by precipitation, both in and below clouds ${ }^{70}$, as well as by dry deposition using a resistance in-series approach ${ }^{71}$. Wet deposition is an important sink process for aerosols larger than about $50-100 \mathrm{~nm}$ in diameter. The model implements wet removal updates developed by Wang et al. ${ }^{72}$ to account for wet removal in mixed-phase and ice clouds. In addition, we use the updated aerosol wet removal scheme developed by Croft et al. ${ }^{7}$ that includes revisions to the wet removal efficiency and precipitation fraction parameterizations to better represent the efficiency of aerosol scavenging, particularly in the low-clouds of the Arctic. The aerosol in-cloud wet removal in GEOS-Chem-TOMAS is specific to the aerosol size range that is assumed activated into cloud hydrometeors, and includes release of particles back to the atmosphere by evaporation of hydrometeors.

\section{Atmospheric Cluster Dynamics Code description. The Atmospheric Cluster} Dynamics Code (ACDC) $)^{35,36}$ was implemented in the GEOS-Chem-TOMAS (GCT) model for this study. ACDC is a state-of-the-science ternary $\mathrm{H}_{2} \mathrm{SO}_{4}-\mathrm{NH}_{3}-\mathrm{H}_{2} \mathrm{O}$ particle formation scheme ${ }^{35,36}$. ACDC is briefly described here and further details are in the Supplementary Methods. The formation rate of particles at circa $1.2 \mathrm{~nm}$ in mass diameter is determined from a full kinetics simulation by ACDC model using particle evaporation rates based on quantum chemistry. The approach is driven entirely by these physicochemical interactions, and its behaviour is not fit to ambient or laboratory observations. The formation rate results of hundreds of ACDC runs, varying sulfuric acid concentrations $\left(10^{4}-10^{9} \mathrm{~cm}^{-3}\right)$, ammonia vapour concentrations $\left(10^{6}-10^{11} \mathrm{~cm}^{-3}\right)$, relative humidity $(0-100 \%)$, temperature $(180-320 \mathrm{~K})$ and condensation (scavenging) sink on existing aerosol surface area $\left(10^{-5}-10^{-1} \mathrm{~s}^{-1}\right)$, were systematically recorded in a comprehensive lookup table for use in the GCT model. With this method, we achieve predictions of ternary formation rates more in line with the original ACDC theoretical model, with only a minor additional computational cost. The newly formed particles added to the GCT model have a diameter of $1.2 \mathrm{~nm}$, corresponding to the size for which the ACDC formation rates were calculated.

The model has been compared with laboratory observations obtained in the CLOUD (Cosmics Leaving OUtdoor Droplets) chamber ${ }^{9}$. It successfully reproduced, with unparalleled quantitative performance, the $\mathrm{H}_{2} \mathrm{SO}_{4}-\mathrm{NH}_{3}$ formation rates across a broad range of ammonia and sulfuric acid gas-phase concentrations. The capability of ACDC to reproduce the observed formation rates is particularly impressive considering that it was not trained to any of the observation data; the model is entirely governed by the aforementioned collision, evaporation and scavenging rate calculations.

Recently, the ACDC-based lookup table has also been used in a regional-scale chemical transport model simulation over Europe and evaluated against both ground site and aircraft measurements from the surface up to $10 \mathrm{~km}$ (ref. 36). The predicted number concentrations agree reasonably well with the measurements resulting in only a slight over-prediction of particles larger than $4 \mathrm{~nm}$. However, it should be noted that in a transport model set-up, the particle formation scheme is only one factor among many (including, for example, condensation, coagulation, wet and dry deposition schemes) affecting the particle size distribution evolution, and the agreement between predicted and observed particle numbers is expected to improve as further improvements to the description of the aerosol microphysics are implemented ${ }^{36}$.

Calculation of cloud-condensation nuclei concentrations. As an additional evaluation of our Arctic simulations, we calculated the cloud-condensation nuclei at $0.2 \%$ super saturation $(\mathrm{CCN} 0.2)$ based on the simulated aerosol number and mass distributions and compared with summertime measurements from the inner Arctic, north of $80^{\circ} \mathrm{N}^{3}$. We calculated the effective hygroscopicity parameter $(\kappa)$ using the composition of each model size bin and then determined the total number of aerosols that could activate at $0.2 \%$ supersaturation based on $\kappa$-Kohler theory ${ }^{73}$. We chose this supersaturation to match available measurements. However, supersaturations in the pristine Arctic environment could easily reach $0.6 \%$ or larger and thus CCN0.2 should not be considered as an exact proxy for cloud-droplet number.

Calculation of Arctic EL-VOC-based particle formation rates. We also conducted calculations to evaluate the possibility of EL-VOCs to contribute to particle formation rates in the Arctic. We use recently presented measurement data 
for the Arctic Ocean, which indicates an air-sea flux of $0.27-0.78 \mu \mathrm{g} \mathrm{m}^{-2} \mathrm{~d}^{-1}$ for monoterpenes ${ }^{7}$. Using the maximum air-sea flux and assuming a yield of 0.03 for EL-VOCs, we find the EL-VOC rate in units of $\mathrm{g} \mathrm{m}^{-2} \mathrm{~s}^{-1}$ :

$$
\text { EL-VOC rate }=0.03 \times\left[0.78 \times 10^{-6} /(24 \times 3600)\right]
$$

We also assume a boundary layer height of $100 \mathrm{~m}$ and a condensation sink of $3.43 \times 10^{-4} \mathrm{~s}^{-1}$ and calculate EL-VOC concentration:

$$
\begin{array}{r}
\mathrm{EL}-\mathrm{VOC}=\mathrm{EL}-\mathrm{VOC} \text { rate } /(\mathrm{CS} \times \mathrm{BL})=7.9 \times 10^{-12} \mathrm{~g} \mathrm{~m}^{-3} \\
=4.0 \times 10^{5} \text { molecules } \mathrm{cm}^{-3}
\end{array}
$$

We then apply the equation (2) of Riccobono et al. ${ }^{75}$ to parameterize the particle formation rate as a function of sulfuric acid and ELVOC:

$$
J=3.27 \times 10^{-21} \mathrm{~cm}^{6} \mathrm{~s}^{-1} \times\left(\mathrm{H}_{2} \mathrm{SO}_{4}\right)^{2} \times(\text { ELVOC })
$$

We use a typical $\mathrm{H}_{2} \mathrm{SO}_{4}$ concentration from our summertime simulations at Alert of $5 \times 10^{6} \mathrm{~cm}^{-3}$ and calculate $J=0.03 \mathrm{~s}^{-1}$. Such a low particle formation rate suggests that typical EL-VOC levels near Alert are likely not sufficient to yield appreciable particle formation, although we cannot rule out their additional contributions. Certainly low-volatility marine organics are expected to play an important role in particle growth and their size-resolved sources in the Arctic are associated with a high degree of uncertainty ${ }^{74}$.

Although our simulations are generally consistent with the current state of knowledge, organic emissions are highly uncertain and not well size resolved for the Arctic ${ }^{76}$. Missing low-volatility organics could suppress particle growth in our simulations, yielding an underestimate of the growth to sizes that act as the seeds for cloud-droplet formation. Alternatively missing primary organic aerosol emissions could suppress particle growth through acting as a greater condensation sink. The role of organics in particle formation and growth in the Arctic is an important subject for future research.

Calculation of CDNC. We make an offline calculation of the CDNC using monthly averaged aerosol number and mass concentrations from our GEOS-Chem-TOMAS simulations. We use the activation parameterization of Abdul-Razzak and Ghan ${ }^{77}$. We assume aerosol constituents are mixed internally within each size bin, and calculate the hygroscopicity parameter, $\kappa$, as a volume weighted average of the individual aerosol constituents ${ }^{73}$. We assume a constant updraft velocity of $0.5 \mathrm{~m} \mathrm{~s}^{-1}$ for the results presented in Fig. $5 \mathrm{a}$.

We examined the maximum supersaturation achieved with an updraft velocity of both 0.1 and $0.5 \mathrm{~m} \mathrm{~s}^{-1}$ at the model level corresponding to approximately $915 \mathrm{hPa}$ (Supplementary Fig. 8). Assuming an updraft velocity of $0.1 \mathrm{~m} \mathrm{~s}^{-1}$ results in a maximum supersaturation in the Arctic region of $0.15-0.25 \%$, while increasing this updraft to $0.5 \mathrm{~m} \mathrm{~s}^{-1}$ results in a noticeably higher supersaturation (in the range of $0.3-0.5 \%$ ), both within a reasonable range for the summertime Arctic.

We also examined the corresponding minimum critical diameters for activation at each updraft velocity (Supplementary Fig. 9). To do this, we used a constant $\kappa$ of 0.4 as a simplifying assumption, to yield about the minimum aerosol size that could activate to form a cloud droplet based on our simulations. However, our full method used to produce the CDNC values presented in Fig. $5 \mathrm{a}$ calculates $\kappa$ for each size bin in each model grid box based on the aerosol composition. These minimum critical diameters range from 80 to $110 \mathrm{~nm}$ for the $0.1 \mathrm{~m} \mathrm{~s}^{-1}$ updraft and 40 to $80 \mathrm{~nm}$ for the $0.5 \mathrm{~m} \mathrm{~s}^{-1}$ updraft.

Calculation of aerosol-induced cloud-albedo radiative effect. To estimate the aerosol-induced cloud-albedo radiative effect (also termed the aerosol indirect effect or AIE), we calculate the change in top-of-the-atmosphere radiation using an offline version of the Rapid Radiative Transfer Model for $\mathrm{GCMs}^{78,79}$. Monthly averaged cloud fraction, temperature, pressure and cloud liquid-water content are from NASA GEOS5 meteorology fields. We first assume a control cloud drop radius of 10 microns and then perturb this value by taking the ratio of the simulated number of activated particles with and without $\mathrm{NH}_{3}$ emissions from seabird guano, to the one-third power ${ }^{48,49}$. We assume constant cloud liquid-water content for the control and perturbed simulations, such that changes in cloud-droplet number are associated with changes in cloud-droplet radius, and thus changes in cloud optical depth. The above methodology is used to calculate the aerosol indirect (cloud-albedo) effect presented in Fig. 5b.

Methodology for exploring uncertainties in AIE. We conducted sensitivity studies to examine the potential impact of uncertainties related to ammonia emissions, MSA, primary organic aerosols and assumptions about cloud updraft velocity on the cloud-albedo radiative effects attributed to seabird-colony ammonia emissions. We examined the effects of both doubling and halving all seabird-colony ammonia emissions (simulations $2 \times \mathrm{xH}_{3}$ and $0.5 \mathrm{xNH} 3$, respectively). In another sensitivity study, we assumed that MSA behaved the same as sulfate and acted along with sulfate in particle formation (simMSA). In addition, we conducted a sensitivity study assuming a constant flux of primary organic aerosol from the ocean of $2.84 \mathrm{\mu g} \mathrm{m}^{-2}$ per day following Browse et al. ${ }^{80}$ (simPOA). Finally, we conducted two sensitivity studies with updraft velocities of 0.1 and $1.0 \mathrm{~m} \mathrm{~s}^{-1}$ (simvel0.1 and simvel1.0, respectively). Some of these uncertainties can strengthen
(2xNH3, simMSA, simvel1.0), whereas others can weaken (0.5xNH3, simPOA, simvel0.1) the indirect effect relative to our standard simulation. Supplementary Table 2 shows that these factors could yield uncertainty of about a factor of two in our calculated pan-Arctic mean aerosol indirect effect. Future work is needed to improve knowledge related to these uncertainties so that better model parameterizations can be developed.

Code availability. The GEOS-Chem-TOMAS model used in this study is freely available for download from www.geos-chem.org. To derive the results presented in this study, additional code modifications to the wet scavenging and particle formation parameterizations are necessary. Additional off-line post-processing scripts are required as well to calculate the changes in cloud properties and radiative effects. This additional code is available from corresponding authors upon request. The E-AIM Model II is accessible online at (http://www.aim.env.uea.ac.uk/ aim/model2/model2a.php).

The seabird-colony ammonia emissions data that were implemented in the GEOS-Chem-TOMAS model are freely available in the NERC Environmental Information Data Centre with the identifier doi:10.5285/c9e802b3-43c8-4b36-a3a38861d9da8ea9. Additional seabird-colony ammonia emissions data are available from the Circumpolar Seabird Data Portal at http://axiom.seabirds.net/maps/js/ seabirds.php.

Data availability. The findings in this study are based on model output from the GEOS-Chem-TOMAS model and measurement data. Requests for the model output can be sent to B.C. (betty.croft@dal.ca), and requests for measurement data can be sent to G.R.W. (greg.wentworth@gov.ab.ca) and W.R.L. (richard.leaitch@canada.ca).

\section{References}

1. IPCC. in Climate Change 2013: The Physical Science Basis. Contribution of Working Group I to the Fifth Assessment Report of the Intergovernmental Panel on Climate Change (eds Stocker, T. F. et al.) (Cambridge Univ. Press, 2013).

2. Shindell, D. \& Faluvegi, G. Climate response to regional radiative forcing during the twentieth century. Nat. Geosci 2, 294-300 (2009).

3. Leck, C. L. \& Svensson, E. Importance of aerosol composition and mixing state for cloud droplet activation over the Arctic pack ice in summer. Atmos. Chem. Phys. 15, 2545-2568 (2015).

4. Leaitch, W. R. et al. Dimethyl sulfide control of the clean summertime Arctic aerosol and cloud. Elem. Sci. Anth 1, 000017 (2013).

5. Browse, J. et al. The scavenging processes controlling the seasonal cycle in Arctic sulphate and black carbon aerosol. Atmos. Chem. Phys. 12, 6775-6798 (2012).

6. Korhonen, H. et al. A global model study of processes controlling aerosol size distributions in the Arctic spring and summer. J. Geophys. Res. 113, D08211 (2008).

7. Croft, B. et al. Processes controlling the annual cycle of Arctic aerosol number and size distributions. Atmos. Chem. Phys. 16, 3665-3682 (2016).

8. Kirkby, J. et al. Role of sulphuric acid, ammonia and galactic cosmic rays in atmospheric aerosol nucleation. Nature 476, 429-433 (2011).

9. Almeida, J. et al. Molecular understanding of sulphuric acid-amine particle nucleation in the atmosphere. Nature 502, 359-363 (2013).

10. Napari, I. et al. Parameterization of ternary nucleation rates for $\mathrm{H}_{2} \mathrm{SO}_{4}-\mathrm{NH}_{3}-\mathrm{H}_{2} \mathrm{O}$ vapors. J. Geophys. Res. 107, 4381 (2002).

11. Charlson, R. J. et al. Climate forcing by anthropogenic aerosols. J. Geophys. Res. 255, 423-430 (1992)

12. Twomey, S. The influence of pollution on the shortwave albedo of clouds. J. Atmos. Sci. 34, 1149-1152 (1977).

13. Lohmann, U. \& Feichter, J. Global indirect aerosol effects: a review. Atmos. Chem. Phys. 5, 715-737 (2005).

14. Wentworth, G. R. et al. Ammonia in the summertime Arctic marine boundary layer: sources, sinks and implications. Atmos. Chem. Phys. 16, 1937-1953 (2016).

15. Giamarelou, M. et al. Indirect evidence of the composition of nucleation mode atmospheric particles in the high Arctic. J. Geophys. Res. Atmos. 121, 965-975 (2016).

16. Johnson, M. T. et al. Field observations of the ocean-atmosphere exchange of ammonia: fundamental importance of temperature as revealed by a comparison of high and low latitudes. Glob. Biogeochem. Cycles 22, GB1019 (2008).

17. Carpenter, L. J. et al. Ocean-atmosphere trace gas exchange. Chem. Soc. Rev. 41, 6473-6506 (2012).

18. Riddick, S. N. et al. The global distribution of ammonia emissions from seabird colonies. Atmos. Environ. 55, 319-327 (2012).

19. Riddick, S. N. et al. Global ammonia emissions from seabirds. NERC Environmental Information Data Centre 10.5285/c9e802b3-43c8-4b36-a3a38861d9da8ea9. https://data.gov.uk/dataset/global-ammonia-emissions-fromseabirds (2012).

20. Riddick, S. N. et al. Measurement of ammonia emissions from tropical seabird colonies. Atmos. Environ. 89, 35-42 (2014). 
21. Weber, R. J. et al. A study of new particle formation and growth involving biogenic and trace gas species measured during ACE 1. J. Geophys. Res. 103, 16385-16396 (1998)

22. Paulot, F. et al. Global oceanic emission of ammonia: Constraints from seawater and atmospheric observations. Glob. Biogeochem. Cycles 29, 1165-1178 (2015).

23. Schobesberger, S. et al. Molecular understanding of atmospheric particle formation from sulfuric acid and large oxidized organic molecules. Proc. Natl Acad. Sci. USA 110, 17223-17228 (2013).

24. $\mathrm{Fu}, \mathrm{P}$. et al. Isoprene, monoterpene, and sesquiterpene oxidation products in the high arctic aerosols during late winter to early summer. Environ. Sci. Technol. 43, 4022-4028 (2009).

25. Legrand, M. et al. A reassessment of the budget of formic and acetic acids in the boundary layer at Dumont d'Urville (coastal Antarctica): The role of penguin emissions on the budget of several oxygenated volatile organic compounds. J. Geophys. Res. Atmos 117, D06308 (2012).

26. Allan, J. D. et al. Iodine observed in new particle formation events in the Arctic atmosphere during ACCACIA. Atmos. Chem. Phys. 15, 5599-5609 (2015).

27. Fisher, J. A. et al. Sources, distribution, and acidity of sulfate-ammonium aerosol in the Arctic in winter-spring. Atmos. Environ. 45, 7301-7318 (2011).

28. Bey, I. et al. Global modeling of tropospheric chemistry with assimilated meteorology: model description and evaluation. J. Geophys. Res. 106, 23073-23095 (2001).

29. Adams, P. J. \& Seinfeld, J. H. Predicting global aerosol size distributions in general circulation models. J. Geophys. Res. 107, 4310-4370 (2002).

30. Seabird Information Network. Circumpolar Seabird Data Portal, available at http://axiom.seabirds.net/circumpolar_portal.php (last access, 2015).

31. Boylan, J. W. \& Russell, A. G. PM and light extinction model performance metrics, goals, and criteria for three-dimensional air quality model. Atmos. Environ. 40, 4946-4959 (2006).

32. Di Pierro, M. et al. Spatial and seasonal distribution of Arctic aerosols observed by the CALIOP satellite instrument (2006-2012). Atmos. Chem. Phys. 13, 7075-7095 (2013).

33. Tunved, P. et al. Arctic aerosol life cycle: linking aerosol size distributions observed between 2000 and 2010 with air mass transport and precipitation at Zeppelin station, Ny-Ålesund, Svalbard. Atmos. Chem. Phys. 13, 3643-3660 (2013).

34. Garrett, T. J. et al. Assessing the relative contributions of transport efficiency and scavenging to seasonal variability in Arctic aerosol. Tellus B 62, 190-196 (2010).

35. Olenius, T. et al. Free energy barrier in the growth of sulfuric acid-ammonia and sulfuric acid-dimethylamine clusters. J. Chem. Phys. 139, 084312 (2013).

36. Baranizadeh, E. et al. Implementation of state-of-the-art ternary new particle formation scheme to the regional chemical transport model PMCAMx-UF in Europe. Geosci. Model Dev. 9, 2741-2754 (2016).

37. Schmale, J. et al. Sub-Antarctic marine aerosol: Dominant contributions from biogenic sources. Atmos. Chem. Phys. 13, 8669-8694 (2013).

38. Stavrakou, T. et al. Satellite evidence for a large source of formic acid from boreal and tropical forests. Nat. Geosci. 5, 26-30 (2011).

39. Orellana, M. V. et al. Marine microgels as a source of cloud condensation nuclei in the high Arctic. Proc. Natl Acad. Sci. USA 108, 13612-13617 (2011).

40. Karl, M. et al. Marine nanogels as a source of atmospheric nanoparticles in the high Arctic. Geophys. Res. Lett. 40, 3738-3743 (2013).

41. Karl, M. et al. A study of new particle formation in the marine boundary layer over the central Arctic Ocean using a flexible multicomponent aerosol dynamic model. Tellus B 64, 17158 (2012).

42. Leck, C. \& Bigg, E. K. New particle formation of marine biological origin. Aerosol Sci. Technol. 44, 570-577 (2010).

43. Perraud, V. et al. The future of airborne sulfur-containing particles in the absence of fossil fuel sulfur dioxide emissions. Proc. Natl Acad. Sci. USA 112, 13514-13519 (2015)

44. Chen, H. et al. Reaction of methanesulfonic acid with amines and ammonia as a source of new particles in air. J. Phys. Chem. B 120, 1526-1536 (2015).

45. Kupiszewski, P. et al. Vertical profiling of aerosol particles and trace gases over the central Arctic Ocean during summer. Atmos. Chem. Phys. 13, 12405-12431 (2013).

46. Leaitch, W. R. et al. Effects of 20-100 nanometre particles on liquid clouds in the clean summertime Arctic. Atmos. Chem. Phys. 16, 11107-11124 (2016).

47. Mauritsen, T. et al. An Arctic CCN-limited cloud-aerosol regime. Atmos. Chem. Phys. 11, 165-173 (2011).

48. Rap, A. et al. Natural aerosol direct and indirect radiative effects. Geophys. Res. Lett. 40, 3297-3301 (2013).

49. Kodros, J. K. et al. The aerosol radiative effects of uncontrolled combustion of domestic waste. Atmos. Chem. Phys. 16, 6771-6784 (2016).

50. Myhre, G. et al. in Climate Change 2013: The Physical Science Basis. Contribution of Working Group I to the Fifth Assessment Report of the Intergovernmental Panel on Climate Change (eds Stocker, T. F. et al.) (Cambridge Univ. Press, 2013).
51. Lawrence, D. M. et al. Accelerated Arctic land warming and permafrost degradation during rapid sea ice loss. Geophys. Res. Lett. 35, L11506 (2008).

52. Mungall, E. et al. Dimethyl sulfide in the summertime Arctic atmosphere: measurements and source sensitivity simulations. Atmos. Chem. Phys. 16, 6665-6680 (2016).

53. Chang et al. Relating atmospheric and oceanic DMS levels to particle nucleation events in the Canadian Arctic. J. Geophys. Res. 116, D00S03 (2011).

54. Corbett, J. J. et al. Arctic shipping emissions inventories and future scenarios. Atmos. Chem. Phys. 10, 9689-9704 (2010).

55. Li, S.-M. \& Barrie, L. A. Biogenic sulphur aerosol in the Arctic troposphere: 1. Contributions to total sulphate. J. Geophys. Res. 98, 20613-20622 (1993).

56. Wexler, A. S. \& Clegg, S. L. Atmospheric aerosol models for systems including the ions $\mathrm{H}^{+}, \mathrm{NH}_{4}^{+}, \mathrm{Na}^{+}, \mathrm{SO}^{2-}, \mathrm{NO}^{-}, \mathrm{Cl}^{-}, \mathrm{Br}^{-}$and $\mathrm{H} 2 \mathrm{O}$. J. Geophys. Res. 107, 4207 (2001).

57. Clegg, S. L. et al. A thermodynamic model of the system $\mathrm{H}^{+}-\mathrm{NH}_{4}{ }^{+}-\mathrm{SO} 4^{2-}$ $\mathrm{NO}^{-}-\mathrm{H} 2 \mathrm{O}$ at tropospheric temperatures. J. Phys. Chem. A 102, 2137-2154 (1998).

58. Meng, Z. \& Seinfeld, J. H. Time scales to achieve atmospheric gas-aerosol equilibrium for volatile species. Atmos. Environ. 30, 2889-2900 (1996).

59. Wilson, L. J. et al. Modelling the spatial distribution of ammonia emissions from seabirds in the UK. Environ. Pollut. 131, 173-185 (2004).

60. Blackall, T. D. et al. Application of tracer ratio and inverse dispersion methods with boat-based plume measurements to estimate ammonia emissions from seabird colonies. Water Air Soil Pollut. Focus 4, 279-285 (2004).

61. Gaston, A. J. et al. Climate change, ice conditions and reproduction in an Arctic nesting marine bird: Brunnich's guillemot (Uria lomvia L.). J. Anim. Ecol. 74, 832-841 (2005).

62. Mallory, M. L. \& Forbes, M. R. Does sea ice constrain the breeding schedules of high Arctic Northern Fulmars? Condor 75, 894-906 (2007).

63. McLaren, P. L. Spring migration and habitat use by seabirds in eastern Lancaster Sound and western Baffin Bay. Arctic 35, 88-111 (1982).

64. Bouwman, A. F. et al. A global high-resolution emission inventory for ammonia. Glob. Biogeochem. Cycles 11, 561-587 (1997).

65. Paulot, F. et al. Ammonia emissions in the United States, European Union, and China derived by high-resolution inversion of ammonium wet deposition data: interpretation with a new agricultural emissions inventory (MASAGE_NH3). J. Geophys. Res. 119, 4343-4364 (2014).

66. van der Werf, G. R. et al. Global fire emissions and the contribution of deforestation, savanna, forest, agricultural, and peat fires (1997-2009). Atmos. Chem. Phys. 10, 11707-11735 (2010).

67. Lana, A. et al. An updated climatology of surface dimethlysulfide concentrations and emission fluxes in the global ocean. Glob. Biogeochem. Cycles 25, GB1004 (2011).

68. D'Andrea, S. D. et al. Understanding global secondary aerosol amount and size-resolved condensational behavior. Atmos. Chem. Phys. 13, 11519-11534 (2013).

69. Fountoukis, C. \& Nenes, A. ISORROPIA II: a computationally efficient thermodynamic equilibrium model for $\mathrm{K}^{+}-\mathrm{Ca}^{2}+-\mathrm{Mg}^{2+}-\mathrm{NH}_{4}^{+}-\mathrm{Na}^{+}-\mathrm{SO}_{4}^{2-}$ $\mathrm{NO}_{3}^{-}-\mathrm{Cl}^{-}-\mathrm{H}_{2} \mathrm{O}$ aerosols. Atmos. Chem. Phys. 7, 4639-4659 (2007).

70. Liu, H. et al. Constraints from ${ }^{210} \mathrm{~Pb}$ and ${ }^{7} \mathrm{Be}$ on wet deposition and transport in a global three-dimensional chemical tracer model driven by assimilated meteorological fields. J. Geophys. Res. 106, 12109-12128 (2001).

71. Wesely, M. L. Parameterization of surface resistances to gaseous dry deposition in regional-scale numerical models. Atmos. Environ. 23, 1293-1304 (1989).

72. Wang, Q. et al. Sources of carbonaceous aerosols and deposited black carbon in the Arctic in winter-spring: implications for radiative forcing. Atmos. Chem. Phys. 11, 12453-12473 (2011).

73. Petters, M. D. \& Kreidenweis, S. M. A single parameter representation of hygroscopic growth and cloud condensation nucleus activity. Atmos. Chem. Phys. 7, 1961-1971 (2007).

74. Hu, Q.-H. et al. Secondary organic aerosols over oceans via oxidation of isoprene and monoterpenes from Arctic to Antarctic. Sci. Rep. 3, 2280 (2013)

75. Riccobono, F. et al. Oxidation products of biogenic emissions contribute to nucleation of atmospheric particles. Science 344, 717-721 (2014).

76. Fu, P. Q. et al. Organic molecular composition of marine aerosols over the Arctic Ocean in summer: Contributions of primary emission and secondary aerosol formation. Biogeosciences 10, 653-667 (2013).

77. Abdul-Razzak, H. \& Ghan, S. J. A parameterization of aerosol activation 3. Sectional representation. J. Geophys. Res. 107, 4026 (2002).

78. Iacono, M. J. et al. Radiative forcing by long-lived greenhouse gases: calculations with the AER radiative transfer models. J. Geophys. Res. 113, D13103 (2008).

79. Heald, C. L. et al. Contrasting the direct radiative effect and direct radiative forcing of aerosols. Atmos. Chem. Phys. 14, 5513-5527 (2014).

80. Browse, J. et al. The complex response of Arctic aerosol to sea-ice retreat. Atmos. Chem. Phys. 14, 7543-7557 (2014). 


\section{Acknowledgements}

NETCARE is supported by the Climate Change and Atmospheric Research programme at NSERC. We thank O. Kupiainen-Määttä, T. Olenius, J. Julin, H. Vehkamäki and I. Riipinen for their support of this project through constructive discussions, suggestions and provision of the Atmospheric Cluster Dynamics Code (ACDC). We thank Sangeeta Sharma, Desiree Toom, Alina Chivulescu, Dan Veber, the Observatory operators at Alert, Andrew Platt and Carrie Taylor for their support of the Environment and

Climate Change (ECCC) aerosol programme at Alert. We thank Kevin Rawlings (www.krawlings.com) for the provision of his photographic image of two Arctic terns on tundra. Our sincere thanks are also extended to Kathy Kuletz of the U.S. Fish and Wildlife Service for her helpful discussions regarding Arctic seabirds. We are grateful for the hard work and dedication of the CCGS Amundsen crew. We also thank Maurice Levasseur, Emma Mungall, Alex Lee, Vickie Irish, Heather Stark and Jeremy Wentzell for help with the Amundsen measurements, for example, during mobilization, demobilization and calibration of the AIM-IC.

\section{Author contributions}

B.C., R.V.M. and J.R.P. led the GEOS-Chem-TOMAS simulations. G.R.W. and J.G.M. led the shipboard $\mathrm{NH}_{3}$ measurements. W.R.L. led the Alert in situ measurements. J.K.K. conducted the off-line radiative forcing calculations. B.N.M. assisted with implementation of the Atmospheric Cluster Dynamics Code into the GEOS-Chem-TOMAS model. J.P.D.A. is the principal investigator of the NETwork on Climate and Aerosols: Addressing key uncertainties in Remote Canadian Environments (NETCARE). All the authors contributed to the writing of this paper.

\section{Additional information}

Supplementary Information accompanies this paper at http://www.nature.com/ naturecommunications

Competing financial interests: The authors declare no competing financial interests.

Reprints and permission information is available online at http://npg.nature.com/ reprintsandpermissions/

How to cite this article: Croft, B. et al. Contribution of Arctic seabird-colony ammonia to atmospheric particles and cloud-albedo radiative effect. Nat. Commun. 7, 13444 doi: $10.1038 /$ ncomms13444 (2016).

Publisher's note: Springer Nature remains neutral with regard to jurisdictional claims in published maps and institutional affiliations.

(c) (1) $\odot$ This work is licensed under a Creative Commons Attributioncc. other third party material in this article are included in the article's Creative Commons license, unless indicated otherwise in the credit line; if the material is not included under the Creative Commons license, users will need to obtain permission from the license holder to reproduce the material. To view a copy of this license, visit http:// creativecommons.org/licenses/by-nc-nd/4.0/

(C) The Author(s) 2016 